\title{
CONSTITUCIONALIZAÇÃO DO DIREITO ADMINISTRATIVO E O DEVIDO PROCESSO LEGAL: A DEMOCRATIZAÇÃO DAS DECISÕES ADMINISTRATIVAS QUE ENVOLVAM INTERESSES DOS ADMINISTRADOS
}

\author{
César Augusto Luiz Leonardo* \\ João Victor Nardo Andreassa**
}

RESUMO: A constitucionalização do direito administrativo é uma das características da Constituição Federal de 1988 e o devido processo legal torna-se essencial no processo administrativo. $\mathrm{O}$ estudo destas premissas se mostra valioso e deste modo, a hipótese de pesquisa é a análise da questão: a constitucionalização do direito administrativo, com o devido processo legal contribuem com a democratização das decisões administrativas que envolvam interesses dos administrados? Utiliza-se o método dedutivo e as pesquisas documentais e bibliográficas constituem os procedimentos metodológicos. Conclui-se que o devido processo é um instrumento para a democratização das decisões administrativas.

PALAVRAS-CHAVE: Administração pública; Ampla Defesa; Contraditório; Direitos fundamentais; Hermenêutica constitucional.

\section{CONSTITUTIONALISATION OF ADMINISTRATIVE LAW AND DUE PROCESS: THE DEMOCRATIZATION OF ADMINISTRATIVE DECISIONS INVOLVING THE INTERESTS OF THE MANAGED}

\begin{abstract}
The constitutionalization of administrative law is one of the characteristics of the Federal Constitution of 1988 and the proper legal process becomes essential in the administrative process. The study of these assumptions is valuable and thus the research hypothesis is the analysis of the question: does the constitutionalization of administrative law, with due process of law, contribute to the democratization of administrative decisions involving interests of the administrated? The deductive method is used, and the documentary and bibliographical researches constitute the methodological procedures. It is concluded that due process is an instrument for the democratization of administrative decisions.
\end{abstract}

KEYWORDS: Public administration; Broad Defense; Contradictory; Fundamental rights; Constitutional hermeneutics.

\footnotetext{
* Possui graduação em Direito e especialização em direito civil e direito processual civil pela Associação Educacional Toledo de Presidente Prudente - SP (2006), mestre (2013) e doutor (2018) em direito processual civil pela Universidade de São Paulo (USP). Atualmente é defensor público - Defensoria Pública do Estado de São Paulo, na Regional de Marília, e leciona as disciplinas de Direito Processual Civil e Direito Processual Constitucional no Curso de Graduação em Direito e no curso de Mestrado em Direito no Centro Universitário Eurípides de Marília - SP (UNIVEM). Endereço postal: Avenida Antônio Borella, no 120, Jardim São Domingos, Marília/SP, CEP: 17514-747. Endereço eletrônico: calleonardo@ univem.edu.br.

${ }^{* *}$ Mestrando em Direito pelo Programa de Estudo Pós-Graduado em Direito - Mestrado, do Centro Universitário Eurípedes de Marília - UNIVEM. Bolsista CAPES/PROSUP na modalidade Auxílio para Pagamento de Taxas. Graduado em Direito pelo Centro Universitário das Faculdades Integradas de Ourinhos - Uni-FIO. Advogado. Endereço postal: Rua Professora Lourdes Rocha David, n 159, Centro, Ribeirão Claro/PR, CEP 86410-000. Endereço eletrônico: jvictornardo1996@hotmail.com.
} 


\section{INTRODUÇÃO}

A constitucionalização do direito se mostra presente nas Constituições modernas, e, de forma mais robusta, naquelas advindas do período pós Segunda Guerra Mundial. Os terríveis acontecimentos deste período expuseram a fragilidade da interpretação fria da lei, sem atenção às Constituições, que detinham um caráter político. Haveria de se ter limites à atuação do Estado, e os limites são os direitos humanos.

Com a elevação da dignidade da pessoa humana e dos direitos fundamentais ao patamar de vetor da interpretação de toda a ordem estatal, as normas não mais poderiam ser interpretadas de maneira isolada, mas sim observando os preceitos fundamentais. Isto também ocorreu com o processo, que, a partir da Constituição Federal de 1988, constitucionalizou os princípios processuais como garantias fundamentais.

A constitucionalização do processo, na Lei Maior, atinge não só a esfera judicial, mas de igual forma a administrativa. O devido processo legal passa a ser obrigatoriamente aplicado a todos que possam ser atingidos por uma ação estatal, na restrição de sua liberdade ou de seus bens. Assim, mostra-se de grande importância o estudo do devido processo legal, bem como dos princípios dele decorrentes, o contraditório e ampla defesa, para a melhor prestação da tutela administrativa ao cidadão.

Desta importância, têm-se a hipótese de pesquisa deste artigo, que é persecução da resposta do questionamento: a constitucionalização do direito administrativo, com o devido processo legal contribuem com a democratização das decisões administrativas que envolvam interesses dos administrados? A resposta desta questão consubstancia o objetivo geral do trabalho, tendo como objetivos específicos a análise da constitucionalização do direito, com ênfase no administrativo brasileiro, do devido processo legal e a democratização das decisões administrativas pela efetivação do devido processo, ampla defesa e contraditório.

O tema proposto será trabalhado pelo método dedutivo, com duas premissas, uma maior tratando da constitucionalização do direito administrativo brasileiro e uma menor, que expõe as características fulcrais do devido processo legal, relacionando as duas premissas para se determinar como o devido processo, contraditório e ampla defesa podem democratizar as decisões administrativas. Utilizar-se-á de pesquisas bibliográficas e documentais como procedimentos metodológicos. 


\section{CONSTITUCIONALIZAÇÃO DO DIREITO ADMINISTRATIVO E O DEVIDO PROCESSO LEGAL: \\ A DEMOCRATIZAÇÃO DAS DECISÕES ADMINISTRATIVAS QUE ENVOLVAM \\ INTERESSES DOS ADMINISTRADOS}

Com relação ao caminho percorrido, por primeiro, será realizada uma análise da interpretação positivista, a era do direito codificado e da pouca eficácia das Constituições, bem como o período pós-guerra, onde a dignidade da pessoa humana passou a figurar como o centro da organização estatal, fazendo-se a necessária correlação com o direito administrativo brasileiro.

Em seguida, será trabalhado o princípio do devido processo legal, com uma explanação de suas origens históricas, seu papel da Carta Magna de 1988, aplicabilidade em todas as formas de processo e a demonstração da importância dos princípios do contraditório e da ampla defesa, que derivam diretamente do devido processo, e garantem uma prestação de tutela mais justa.

Por fim, será discutido como o devido processo legal, o contraditório e a ampla defesa tornam a decisão administrativa mais democrática, inserindo-se as considerações sobre a relevância daqueles para uma hermenêutica constitucional propiciada a todos. Ao fim, chega-se a uma conclusão sobre o tema apresentado.

\section{A CONSTITUCIONALIZAÇÃO DO DIREITO ADMINISTRATIVO BRASILEIRO}

O direito administrativo brasileiro, de igual forma como era em diversos países, por muito tempo foi visto como um ramo isolado do direito. Tal isolamento não era característica somente do ramo administrativo, mas de todos os outros. A história jurídica demonstra que a importância de uma Constituição na gerência jurídica é recente, e, anteriormente, as codificações detinham os mandamentos essenciais.

Neste passo, o mandamento constitucional não era autêntica norma jurídica imperativa, mas apenas uma proclamação de valores e diretrizes políticas que deveriam inspirar o legislador, mas não poderiam ser aplicados diretamente aos casos concretos postos ao judiciário (BINENBOJM, 2014, p. 61). Na perspectiva do direito administrativo, este pensamento fica claro na frase escrita no prefácio da obra de Otto Mayer (1923 apud MARQUES NETO; FREITAS, R., 2018, p. 622): “O Direito Constitucional passa. O Direito Administrativo Fica".

Tal movimento remonta ao positivismo jurídico. A partir da Revolução Francesa, o magistrado foi proibido de interpretar a lei, cabendo a ele, apenas, aplicar a lei (CAMBI, 2018, p. 332). Tinha-se a legislação como íntegra, havendo uma rígida separação entre 
judiciário e legislativo, cabendo àquele, nos momentos de dúvida, conflito, obscuridade ou ausência de lei, comunicar o legislativo, para que autorizasse uma interpretação normativa (CAMBI, 2018, p. 332).

Havia uma simbiose plena do direito com a lei que era perseguida pelos países da Europa Continental, por meio do modelo de codificação (CAMBI, 2018, p. 101). Buscando se afastar da bagunça normativa do Ancien Régime francês, a codificação consagrava uma razão universal pelo princípio da igualdade, contra privilégios estatais, sendo que, para este objetivo, o direito deveria ser único, geral e abstrato, garantindo segurança jurídica e a defesa da economia capitalista de expansão (CAMBI, 2018, p. 101).

Binenbojm (2014, p. 61-62) elenca que nos países de sistema jurídico romanogermânico, esta visão correspondeu ao período do "logicentrismo", onde a lei era a vontade geral do povo, e o juiz seria mero reprodutor da lei.

Com relação a hermenêutica, Bonavides (2019, p. 464) explica que este método de interpretação era o objetivista, de grande popularidade no Século XIX, onde se propunha uma autonomia total das leis, de maneira que se afastava de suas origens, sendo que era plena e capaz de se amoldar as mudanças sociais que se iriam aplicar.

Entretanto, vários fatores contribuíram para o declínio do modelo de codificação e a ascensão do que Binenbojm (2014, p. 62) chama de um "novo paradigma jurídico, no qual se vai atribuir às Constituições um novo papel muito mais destacado no sistema normativo".

A crise do Estado liberal-burguês e a chegada do Welfare State ocasionaram um processo de inflação legislativa, pois, o Estado, que antes deveria se manter distante das relações econômico-privadas, agora haveria de intervir neste campo, com a produção cada vez maior de novas normas (BINENBOJM, 2014, p. 62). Teve-se como consequência a desvalorização da lei e a construção de microssistemas normativos destoantes do modelo de inspiração liberal (BINENBOJM, 2014, p. 62).

Mais adiante, a Segunda Guerra Mundial escancarou ao mundo o poder destrutivo dos regimes totalitários. A pessoa humana tratada de maneira irrelevante a estes governos, de modo que eram utilizados em experiências científicas inescrupulosas ou destinadas ao extermínio. Desta barbárie emergiu a imperiosidade de definição de limites jurídicos para as ações do Estado, inclusivo o parlamento (BINENBOJM, 2014, p. 62).

Estes limites jurídicos dizem respeito aos direitos humanos. Os direitos humanos, consubstanciados nas Constituições, ganhando caráter fundamental, servem de óbice as ações 


\title{
CONSTITUCIONALIZAÇÃO DO DIREITO ADMINISTRATIVO E O DEVIDO PROCESSO LEGAL: \\ A DEMOCRATIZAÇÃO DAS DECISÕES ADMINISTRATIVAS QUE ENVOLVAM \\ INTERESSES DOS ADMINISTRADOS
}

dos poderes estatais. Esta barreira atinge, inclusive, o por constituinte originário, que deve observar os princípios fundamentais para a realização da lei organizacional da sociedade.

O direito à boa administração pública, composto de regras e princípios relacionados aos direitos fundamentais, desponta como vetor máximo das aplicações normativas, de maneira a promover o bem universal, livre, justo e solidário, buscando combater a pobreza e garantir um desenvolvimento sustentável da sociedade (FREITAS, J., 2013, p. 20). Na retomada à democracia, a Constituição Federal de 1988 trouxe esta perspectiva, como ensina Sarlet:

\begin{abstract}
Dentre as inovações, assume destaque a situação topográfica dos direitos fundamentais, positivados no início da Constituição, logo após o preâmbulo e os princípios fundamentais, o que, além de traduzir maior rigor lógico, na medida em que os direitos fundamentais constituem parâmetro hermenêutico e valores superiores de toda a ordem constitucional e jurídica, também ao encontro da melhor tradição do constitucionalismo na esfera dos direitos fundamentais (SARLET, 2015, p. 67).
\end{abstract}

Destaca-se, também, o momento histórico brasileiro, saindo de um período autoritário de 21 anos. Os direitos fundamentais assumiram, assim, grande relevância como uma reação à época ditatorial, sendo possível se traçar um paralelo entre a Constituição Federal brasileira de 1988 e as Constituições do segundo Pós-Guerra, por exemplo, a Constituição italiana de 1947 e a Lei Fundamental da Alemanha, de 1949, bem como a Constituição da República Portuguesa de 1976 e a Constituição espanhola de 1978, sendo estas duas advindas de regimes autoritários anteriores, em uma redemocratização de seus países, tendo forte influência na Lei Maior de 1988 (SARLET, 2015, p. 67).

A Carta Magna prescreveu vários direitos fundamentais civis, sociais e políticos, inaugurando uma nova fase da Administração Pública brasileira. A lei ordinária, oriunda de codificação e afastada da matéria constitucional, não haveria de ser mais a fonte única para o administrador. Como ensina Binenbojm:

A constitucionalização do direito administrativo convola a legalidade em juridicidade administrativa. A lei deixa de ser o fundamento único e último da atuação da Administrativa Pública para se tornar apenas um dos princípios dos sistema de juridicidade instituído pela Constituição. [...] Assim, o agir administrativo pode encontrar espeque e limite diretamente em regras ou princípios constitucionais, dos quais decorrerão, sem necessidade 
de mediação do legislador, ações ou omissões da Administração (BINENBOJM, 2014, p. 70-71).

Os princípios fundamentais ganham protagonismo e os atos administrativos devem observá-los, sem, contudo, violar-se o princípio da legalidade, gerando decisões arbitrárias e solipsistas.

\begin{abstract}
O que se mostra inaceitável é o viés da vinculação absoluta às regras legais. Daí não segue qualquer acolhida nefelibata de extremismos "principiológicos" de caráter arbitrário. Ao contrário. Rejeita-se todo e qualquer decisionismo irracional e hiperbólico, sem modulações e nefasto à racionalidade dialógica, assim como o servilismo dos esbulhadores da juridicidade, presos a desvios sistemáticos de abordagem, tais como o viés da confirmação, de acordo com o qual veem apenas o que querem ver (FREITAS, J., 2013, p. 21).
\end{abstract}

Entre alguns marcos relevantes implementados pela Constituição de 1988 estão a introdução ou ampliação de mecanismos importantes, como a estabilidade, obrigação de investidura por concurso público, reserva de competências, entre outros (MARQUES NETO; FREITAS, R., 2018, p. 624). De igual forma, Costin reforça:

\begin{abstract}
No que concerne à Administração Pública, o novo contexto democrático possibilitou ao cidadão inúmeros canais adicionais para manifestar suas demandas, críticas e sugestões sobre os serviços públicos que lhe eram fornecidos aos políticos ou diretamente à máquina pública, criando assim condições para a construção de um setor público orientado ao cidadão. Além disso, o fortalecimento do instituto do concurso público, se, em alguns casos, gerou irracionalidades (como a dificuldade de contratação de professores ou pesquisadores estrangeiros para as Universidades, posteriormente sanada pela Emenda Constitucional), por outro, ajudou a remover alguns elementos remanescentes do sistema patrimonialista (COSTIN, 2010, p. 63).
\end{abstract}

Pode-se observar que a Constituição Federal de 1988 representou um avanço na participação popular na Administração Pública, bem como propicia, por meio de institutos positivados no texto constitucional, a impugnação direta a atos administrativo que atinjam interesses próprios dos administrados, ou até mesmo que se refiram a coletividade.

A Constituição regulamenta a ordem jurídica da sociedade, e, para isto, é necessário que realize três funções (NERY JUNIOR, 2016, p. 50). A primeira é a integração, sendo que a Constituição tem a função de integrar e formar uma unidade política e do Estado, pois 
assegura um ordenamento jurídico e um processo organizado para dirimir os conflitos que surgirem em seu bojo (NERY JUNIOR, 2016, p. 50).

A segunda é a organização, uma vez que, além da necessidade de formação e conservação da unidade política, deverá, de igual forma, organizar os órgãos estatais constituídos para este fundamento (NERY JUNIOR, 2016, p. 50).

A terceira função é a direção jurídica, visto que a Lei Maior confere existência ao Estado, devendo ser legítima e de acordo com a história, para que se possa conferir aos direitos fundamentais força vinculante para todo o ordenamento jurídico (NERY JUNIOR, 2016, p. 50-51). Com essas três funções, a Constituição passa a ser o direcionamento fundamental da sociedade (NERY JUNIOR, 2016, p. 51).

Sendo este vetor direcional da sociedade, os direitos fundamentais consubstanciados na Constituição Federal devem ser utilizados pelos administradores estatais na realização das atividades típicas para a promoção da organização social. Com este enfoque ao direito fundamental à boa administração pública, quando a administração estiver a tratar de direitos que envolvam os interesses dos administrados, os atos por ela realizados deverão, necessariamente, contar com a participação do interessado. Esta é uma das funções do princípio do devido processo legal, chamar o cidadão a integrar a relação administrativa.

O devido processo legal administrativo é uma garantia constitucional fundamental, disciplinada no texto da Constituição e, desta forma, integrante da nova hermenêutica constitucional que se estabeleceu a partir da Carta Magna de 1988, abarcando-se, dentro do princípio do devido processo, o contraditório e a ampla defesa.

\section{O DEVIDO PROCESSO LEGAL E SUA APLICAÇÃO NO ÂMBITO ADMINISTRATIVO}

Com o fenômeno da constitucionalização do processo, inerente, em um primeiro momento, ao plano judicial, indubitavelmente também atingiu o processo administrativo. Os atos administrativos que atingem interesses de administrados não podem mais serem realizados sem se dar a oportunidade de defesa ao cidadão. Verifica-se, assim, um direito administrativo mais compactuado com as diretrizes constitucionais, afinadas com os direitos fundamentais. 
Apesar dos estudos a serem apresentados dizerem respeito ao processo civil brasileiro, estes importam em grande valia para o desenvolvimento do processo administrativo. Os estudos relacionados ao devido processo legal, bem como o contraditório e a ampla defesa, aplicam-se à esfera administrativa.

A origem histórica do preceito fundamental do devido processo legal está na Magna Charta de João Sem-Terra, no ano de 1215, sem, entretanto, mencionar o termo devido processo legal, sendo este utilizado apenas em lei inglesa de 1354, no reinado de Eduardo III, denominada Statute of Westminster of the Liberties of London (NERY JUNIOR, 2016, p. 107).

Como se observa, a origem do princípio é inglesa, chegando aos Estados Unidos no século XVII, com a V e XIV Emendas à Constituição Federal norte-americana, sendo que, antes disto, as Constituições de Maryland, Pensilvânia e Massachussetts já consagravam este princípio (ALVIM; THAMAY; GRANADO, 2014, p. 26).

No Brasil, a Constituição Federal de 1988 disciplina expressamente o devido processo legal, o contraditório e a ampla defesa, como sendo preceitos fundamentais do Estado, por meio do artigo $5^{\circ}$, incisos LIV, "ninguém será privado da liberdade ou de seus bens sem o devido processo legal” (BRASIL, 1988) e LV, “aos litigantes, em processo judicial ou administrativo, e aos acusados em geral são assegurados o contraditório e ampla defesa, com os meios e recursos a ela inerentes" (BRASIL, 1988).

Houve um grande progresso quanto ao tratamento do devido processo, contraditório e ampla defesa na Constituição Federal de 1988 em relação à suas antecessoras, pois estas garantias se aplicam a toda forma de processo, seja ela penal, civil ou administrativa (ZUFELATO, 2019, p. 42).

Nota-se a predileção constitucional por um processo mais democrático e justo, em todas as esferas do Estado. Faz-se oportuna a explicação de Nery Junior sobre os sentidos do devido processo legal para melhor se entender o caráter garantidor deste princípio.

Em sentido genérico, deve-se aplicar o princípio do devido processo legal à todas as demandas que tenham por objeto direitos relacionados com o trinômio vida-liberdadepropriedade (NERY JUNIOR, 2016, p. 110), uma vez que, tudo que tutelar direitos relacionados a este trinômio estará coberto pelo devido processo legal (ALVIM; THAMAY; GRANADO, 2014, p. 29). 


\section{CONSTITUCIONALIZAÇÃO DO DIREITO ADMINISTRATIVO E O DEVIDO PROCESSO LEGAL: \\ A DEMOCRATIZAÇÃO DAS DECISÕES ADMINISTRATIVAS QUE ENVOLVAM \\ INTERESSES DOS ADMINISTRADOS}

Em sentido material, a cláusula do devido processo legal não indica apenas uma tutela processual, mas um aspecto substancial, tratando-se de direitos materiais e a tutela desses direitos por intermédio do processo administrativo ou judicial (NERY JUNIOR, 2016, p. 110).

Do devido processo, derivam diretamente os princípios constitucionais da isonomia, juiz e promotor natural, inafastabilidade do controle jurisdicional (princípio do direito de ação), contraditório e ampla defesa, proibição da prova ilícita, publicidade dos atos processuais, duplo grau de jurisdição, motivação das decisões administrativas, presunção de não culpabilidade e, por fim, celeridade e da razoável duração do processo (NERY JUNIOR, 2016, p. 127).

Para o estudo da democratização do processo na esfera administrativa, será dado maior enfoque aos princípios do contraditório e ampla defesa, decorrentes do devido processo legal e que garantem a participação efetiva do cidadão na decisão da Administração Pública.

Iniciando-se pelo contraditório, como preleciona Zufelato (2019, p. 42), este é figura fulcral do devido processo, uma vez que, em resultado daquele, as partes podem se manifestar em defesa de seu direito, razão pela qual o texto constitucional consagra as duas facetas do princípio do contraditório com a expressão clássica contraditório e ampla defesa. Câmara (2016, p. 10), de igual maneira, exalta o contraditório como sendo a "nota essencial" do processo, sendo sua característica fundamental.

O contraditório se afigura como uma ferramenta para realização dos direitos de informação e possibilidade de reação (NEVES, 2019, p. 40), necessários à um Estado Democrático de Direito. De tal modo, Câmara complementar sobre este viés:

\footnotetext{
Ora, se no Estado Democrático de Direito não se pode prescindir dos direitos de comunicação e participação, então é preciso considerar que o direito ao contraditório é um dos pilares do Estado Constitucional brasileiro. Afinal, o contraditório precisa ser compreendido como uma garantia de participação dos interessados na formação do resultado da atividade estatal com possibilidade de influência na formação desse resultado (CÂMARA, 2017, p. 45).
}

O contraditório impõe limites à autoridade julgadora e contribui para a melhor solução da controvérsia, dado que as partes atuam no processo com suas alegações, provas e 
discussões sobre a matéria de direito, pondo motivos para acolhimento ou rejeição de pedidos, entre outros (ZUFELATO, 2019, p. 46).

Em comentário ao Processo Civil, mas aplicável à relação administrativa, Theodoro Júnior (2016, p. 8) explana: “As decisões judiciais não podem surpreender a parte que terá de suportar suas consequências, porque o contraditório moderno assegura o direito dos sujeitos do processo de não só participar da preparação do provimento judicial como de influir na sua formação".

Já a ampla defesa diz respeito a permissão às partes para deduzirem as adequadas alegações que sustentam sua pretensão no processo civil, eleitoral, trabalhista e administrativo, com a possibilidade de produção de provas dessas alegações e a interposição dos recursos cabíveis contra as decisões (NERY JUNIOR, 2016, p. 283).

Os destinatários da ampla defesa são os acusados em geral e os litigantes, sendo que a Constituição garante o direito de deduzir alegações e provas adequadas, que possam efetivamente fazer valer a defesa ou pretensão nos processos judiciais e administrativos (NERY JUNIOR, 2016, p. 283).

Como disserta Nery Junior (2016, p. 283), as alegações deduzidas de nada servem se não puderem ser provadas, pois de nada adiantaria garantir o direito de alegar e retirar o direito de provar as alegações. Desta maneira, o direito à prova é intimamente ligado com a ampla defesa e dela é indissociável.

Adentrando no direito administrativo, o devido processo legal pressupõe que o administrado tenha o direito de formular alegações, apresentando documentos antes da decisão, devendo ser levados em conta na decisão a ser proferida pelo órgão competente (FRETAS, J., 2013, p. 86).

Trata-se de silenciosa e vertical transformação do estilo das decisões administrativas brasileiras: em lugar do unilateralismo repudiável e enviesado, a extinção do contrato público, por exemplo, somente poderá ser efetuada se precedida de processo administrativo, sob pena de mácula irremediável. Outro exemplo: a anulação de aposentadoria só poderá ser consumada se precedida do devido processo (FREITAS, J., 2013, p. 86).

O devido processo legal administrativo se consubstancia, em âmbito da Administração Pública federal, na Lei 9.784/1999, pelo artigo $2^{\circ}$, caput, determinando que “a Administração Pública obedecerá, dentre outros, aos princípios da legalidade, finalidade, 
motivação, razoabilidade, proporcionalidade, moralidade, ampla defesa, contraditório, segurança jurídica, interesse público e eficiência” (BRASIL, 1999), e Parágrafo Único, inciso $\mathrm{X}$, pela "garantia dos direitos à comunicação, à apresentação de alegações finais, à produção de provas e à interposição de recursos, nos processos de que possam resultar sanções e nas situações de litígio" (BRASIL, 1999).

Já o artigo $3^{\circ}$ prescreve os direitos dos administrados, que se relacionam diretamente com o devido processo administrativo, ampla defesa e contraditório, sem prejuízo de todos os outros direitos que lhes são assegurados.

\begin{abstract}
Art. $3^{\circ} \mathrm{O}$ administrado tem os seguintes direitos perante a Administração, sem prejuízo de outros que lhe sejam assegurados: I - ser tratado com respeito pelas autoridades e servidores, que deverão facilitar o exercício de seus direitos e o cumprimento de suas obrigações; II - ter ciência da tramitação dos processos administrativos em que tenha a condição de interessado, ter vista dos autos, obter cópias de documentos neles contidos e conhecer as decisões proferidas; III - formular alegações e apresentar documentos antes da decisão, os quais serão objeto de consideração pelo órgão competente; IV - fazer-se assistir, facultativamente, por advogado, salvo quando obrigatória a representação, por força de lei (BRASIL, 1999).
\end{abstract}

Tais direitos atinentes aos administrados na esfera federal, demonstram a constitucionalização das leis ordinárias, que devem seguir a Lei Maior, de forma a agir conforme os direitos fundamentais.

No processo administrativo, o contraditório ganha maior importância na construção de um processo democrático, pois a Administração Pública é parte e julgadora ao mesmo tempo, fazendo-se necessária a utilização da garantia fundamental do contraditório e ampla defesa para que o administrado possa ter o poder de interferir na decisão administrativa. Sobre o tema, Câmara preleciona:

Registre-se que no processo administrativo, dada a inevitável desigualdade de posições entre seus sujeitos (já que a Administração Pública é parte do processo mas é, também, a julgadora, ainda que atuando por órgãos distintos e com autonomia funcional), a garantia do contraditório se faz ainda mais relevante, já que importante mecanismo garantidor da legitimidade democrática das decisões, as quais só poderão ser tidas por constitucionalmente legítimas se for assegurado ao administrado o direito de participar com influência da formação do resultado do processo, não sendo por este surpreendido, uma vez que garantida a possibilidade de prévio 
debate de todos os argumentos que podem em tese vir a ser empregados como fundamentos da decisão a ser proferida (CÂMARA, 2017, p. 50).

Portanto, a constitucionalização do processo brasileiro, com a integralização dos direitos fundamentais, pelo enfoque na dignidade da pessoa humana, na construção de um direito administrativo mais participativo, e o devido processo legal, com seus princípios derivados do contraditório e ampla defesa, podem ser ferramentas valiosas para a democratização das decisões administrativas.

\section{A DEMOCRATIZAÇÃO DAS DECISÕES ADMINISTRATIVAS PELA EFETIVAÇÃO DO DEVIDO PROCESSO, AMPLA DEFESA E CONTRADITÓRIO}

O direito administrativo não mais se interpreta apenas com o olhar à legislação ordinária. O direito constitucional assume o protagonismo dirigente, abandonando-se a concepção unicamente política que antes lhe era aplicada. As codificações cedem espaço para a dignidade da pessoa humana, os direitos fundamentais e, no caso específico da Administração Pública, o direito fundamental à boa administração, que, pela Carta Magna, guiam as ações dos agentes estatais.

Nisto, os princípios processuais constitucionais passaram a se aplicar em todas as formas ao processo, incluindo o administrativo. Em vista disto, é oportuna a diferenciação entre o procedimento administrativo e o processo administrativo. Nery Junior (2016, p. 249) ilustra que "o processo é o meio pelo qual se exercita o direito de ação; o procedimento é a forma pela qual se desenvolvem os atos em geral, incluídos os atos processuais”. Nery Junior ainda exemplifica:

Quando o poder público instaura expediente destinado a objetivo que não seja impor sanção nem de criar direito ou obrigação ao administrado ou a terceiro, não há processo, mas simplesmente procedimento administrativo. Assim, por exemplo, a instauração de sindicância, cuja finalidade é a de investigar a existência de fato (materialidade) ou de quem o praticou (autoria), não caracteriza processo, mas sim procedimento administrativo (NERY JUNIOR, 2016, p. 250).

Assim, como há processo administrativo, deve-se aplicar a estes as garantias processuais positivadas no texto constitucional, do devido processo legal, ampla defesa e contraditório. Encontra-se um avanço no tratamento processual administrativo. O devido 
processo assegura o desdobramento adequado a um Estado Democrático de Direito, ou seja, sem abusos e autoritarismos.

Como norteador das ações feitas pelos administradores estatais, os direitos fundamentais constituem esta segurança ao administrado de que as escolhas administrativas serão feitas de maneira a se buscar o melhor ao cidadão, e não mais com arbitrariedade e de acordo com as convicções e interesses pessoais dos que detém o poder.

O devido processo, dentro desta finalidade, assume um papel de grande importância, pois garante que o cidadão não terá restrições pela via administrativa, sem que se tenha o direito de participar do processo decisório. Freitas, destacando o caráter garantidor do direito fundamental à boa administração pública ao devido processo, expressa:

\begin{abstract}
Mister, então, sulcar que o "devido processo", tomado na justa conta, afinase com a preconizada transformação paradigmática, isto é, promove-se a qualificada mudança de estilo de controle sistemático das escolhas administrativas (também na determinação de noções indeterminadas), em lugar da postura automatista e impulsiva (não raro, prepotente e arbitrária, por ação ou por omissão). Em outras palavras, sensivelmente aplicado às relações administrativas, o princípio do "devido processo" é garantia-matriz de suma importância à concretização do direito fundamental à boa administração pública, no sentido de que ninguém poderá ser afetado em seus interesses legítimos sem que, antes, devam ser ponderadas as suas razões, no pleno e medular exercício da racionalidade do tipo dialógico (FREITAS, J., 2013, p. 87).
\end{abstract}

Inserindo-se dentro do devido processo legal, para além da necessária observação do contraditório e ampla defesa, a deliberação administrativa haverá de ser célere, realizada em uma razoável duração, por uma autoridade julgadora natural e com a publicidade inerente a todo processo constitucionalmente adequado em um Estado Democrático de Direito. Na lição de Freitas:

Por certo, a garantia do contraditório e da ampla defesa não deve ser vista em desarmonia com o princípio do juiz natural, nem com o aludido princípio da publicidade, tampouco com a garantia de meios e resultados processuais aceitáveis. Tal assertiva vale para todas as províncias do sistema jurídico, contudo indispensável cuidar que, no campo das relações administrativas, assuma papel maiúsculo, seja no controle da regularidade de qualquer decisão, seja no exame dos limites da "política administrativa", seja na duração razoável dos processos e, ainda, para robustecer os demais princípios garantidores dos direitos fundamentais (FREITAS, J., 2013, p. 87$88)$. 
A administração pública tem o dever de averiguar e realizar todas as dilações devidas à boa resolução da contenda administrativa. Sobre as dilações, destaca-se que existem as dilações devidas e as dilações indevidas. É direito de todos um processo em que não ocorra dilações indevidas, e, de igual forma, ninguém tem direito a um processo sem as dilações devidas (CÂMARA, 2016, p. 8). Prazos plausíveis para a realização de atos relevantes ao processo demandam tempo, mas, dado que essas dilações são devidas, estas são compatíveis com as garantias constitucionais do processo (CÂMARA, 2016, p. 8). Sobre este aspecto, Freitas complementa:

\footnotetext{
Por todo o articulado, imperioso acolher uma visão finalista do devido processo administrativo, ao menos se se quiser o controle sistemático que vença os óbices à hierarquização axiológica adequada, sem hesitações. $\mathrm{O}$ controle sistemático precisa ser célere, ou melhor, respeitar o tempo razoável. Controle que tarda é descontrole. Entretanto, o controle célere demais revela precipitação irreflexiva (FRETAS, J., 2013, p. 88).
}

Por isto, um processo devidamente conduzido, com o respeito as prerrogativas do administrado, como prazos e recursos, e a apreciação da autoridade julgadora de todos os argumentos postos, garante uma solução mais adequada ao caso concreto que se põe à Administração Pública e ao cidadão.

Marques Neto e Freitas, R. (2018, p. 633), ressaltam que o devido processo legal, introduzido pela Constituição Federal de 1988 ao processo administrativo, trouxe uma nova perspectiva para as ações da Administração Pública.

A prescrição do art. $5^{\circ}, \mathrm{LV}$, da CRFB espraia seus efeitos para além da garantia do devido processo legal, qualificado pelo exercício do contraditório e da ampla defesa. Talvez nem o próprio constituinte tivesse noção clara do impacto que teria a constitucionalização da noção de "processo administrativo" e fazer com que a decisão da Administração se submetesse ao devido processo e aos cânones do contraditório. Essa singela prescrição alavancou uma verdadeira revolução do devir administrativo (MARQUES NETO; FREITAS, R., 2018, p. 633).

Não há mais espaço para abusividades e discricionariedades infundadas. Os atos administrativos devem ser consubstanciados com a participação direta dos administrados, ainda mais quando se tratar de direito que a ele lhe afeta diretamente. 
O devido processo legal administrativo realiza uma valiosa contribuição na democratização da atividade administrativa, quando cede ao cidadão a oportunidade de este depositar sua interpretação. Com isto, a hermenêutica realizada é multifacetária, sendo a decisão administrativa fruto da interpretação dos fundamentos do administrado e administrador.

Como se verifica na concepção de Häberle (2002, p. 38), a democracia é formada pela associação do cidadão. Desta forma, o devido processo, que possibilita a participação do administrado na tarefa estatal, faz com que o cidadão possa influir, inclusive, interpretando conforme à Constituição. A hermenêutica constitucional não pode ser limitada aos intérpretes coorporativos, autorizados juridicamente ou funcionalmente pelo Estado, pois implicaria em um empobrecimento ou auto engodo em relação à Constituição (HÄBERLE, 2002, p. 34) e, por consequência, também da qualidade da prestação administrativa.

Desta maneira, como consequência da constitucionalização do direito administrativo e dos princípios processuais na busca de um processo constitucionalmente adequado, o princípio do devido processo legal, juntamente os princípios do contraditório e da ampla defesa, afirmam a democratização das decisões administrativas, pois estas não mais são produtos das autoridades administrativas julgadoras.

As decisões têm o potencial de expor uma inter-relação entre o direito pleiteado pelo administrativo e pela Administração Pública, de modo a garantir uma participação efetiva do cidadão nos atos administrativos que impactem diretamente em sua vida. A boa administração pública deve trabalhar com o escopo de efetivar os direitos fundamentais e o devido processo legal se mostra uma preciosa ferramenta a serviço do Estado.

\section{CONCLUSÃO}

A interpretação puramente literal da legislação ordinária não se mostra mais adequada para o resguardo dos anseios da sociedade. É preciso de que os direitos fundamentais sejam os condutores das ações dos administradores públicos.

A dignidade da pessoa humana, o direito fundamental à boa administração pública e as garantias constitucionais, como o devido processo legal, o contraditório e ampla defesa, são pontos de partida e, ao mesmo tempo, limites ao Estado. 
Convém esclarecer que não se está a defender o rompimento com o princípio da legalidade e favorecer decisões arbitrárias. $\mathrm{O}$ efeito da constitucionalização dos direitos administrativos e a aplicação do devido processo nas causas administrativas é o inverso. Garante-se a isonomia de julgamento, a fundamentação da decisão, levando em consideração os argumentos postos pelos administrados, em uma verdadeira democratização da decisão administrativa.

Para que estes efeitos sejam sentidos, é preciso que o devido processo legal seja implementado em sua completude. No processo administrativo, pois, é imprescindível a comunicação de todos os atos realizados ao administrado, para que este tome ciência do feito e possa, em um prazo razoável, oferecer sua resposta. A partir desta resposta, deverá a autoridade administrava julgadora decidir com base nos argumentos da Administração Pública como parte e do cidadão interessado. Ainda, desta decisão, haverá de se ter o direito de recurso à segunda instância administrava.

Deste modo, terá sido efetivado o devido processo e a democratização, pela oportunidade de participação do administrado. A decisão será produto da hermenêutica da Administração e do cidadão, e não apenas a imposição de uma vontade administrativa unilateral.

O processo é o meio adequado e garantidor de uma prestação do bem da vida. A constitucionalização dos seus princípios demonstra a preocupação do constituinte em asseverar a produção da tutela estatal de qualidade e justa. O devido processo legal é de grande serventia ao Estado Democrático de Direito.

Por fim, expressa-se que a primeira premissa, maior e verdadeira, demonstra que o direito administrativo se constitucionalizou, tendo os direitos fundamentais a finalidade de ser o norte a ser seguido pelos administradores públicos.

A segunda premissa, menor e igualmente verdadeira, esclarece que o devido processo, o contraditório e a ampla defesa são garantias fundamentais de que o administrado terá participação efetiva na resolução do julgamento administrativo.

Da análise dedutiva dessas duas premissas verdadeiras se conclui que a constitucionalização do direito administrativo, com o devido processo legal contribuem com a democratização das decisões administrativas que envolvam interesses dos administrados, porquanto a participação efetiva do cidadão e a hermenêutica constitucional por ele realizada fazem com que as disposições administrativas sejam mais cooperativas e menos arbitrárias. 


\section{REFERÊNCIAS}

ALVIM, Eduardo Arruda; THAMAY, Renna Faria Kruger; GRANADO, Daniel William. Processo constitucional. $-1^{\text {a }}$ ed. - São Paulo: Revista dos Tribunais, 2014.

BINENBOJM, Gustavo. Uma teoria do direito administrativo: direitos fundamentais, democracia e constitucionalização. - 3 ${ }^{\mathrm{a}}$ ed. - Rio de Janeiro: Renovar, 2014.

BONAVIDES, Paulo. Curso de direito constitucional - 34 ed. - atual. - São Paulo: Malheiros, 2019.

BRASIL. [Constituição (1988)]. Constituição da República Federativa do Brasil de 1988. Disponível em: <http://www.planalto.gov.br/ccivil_03/constituicao/constituicao.htm>. Acesso: 10 jul. 2019.

BRASIL. Lei $\mathbf{n}^{0}$ 9.784, de 29 de janeiro de 1999. Regula o processo administrativo no âmbito da Administração Pública Federal. Brasília, DF: Presidência da República, 1999. Disponível em: <http://www.planalto.gov.br/ccivil_03/leis/19784.htm>. Acesso em: 01 ago. 2019.

CÂMARA, Alexandre Freitas. O novo CPC, o contraditório e a fundamentação das decisões no processo administrativo. Revista Jurídica da Escola Superior de Advocacia da OABPR, Curitiba, v.2, n.2, p. 41-58, ago. 2017. Disponível em:

<http://revistajuridica.esa.oabpr.org.br/wp-content/uploads/2016/04/4-0-revista-juridica.pdf>. Acesso em: 12 ago. 2019.

CÂMARA, Alexandre Freitas. O novo processo civil brasileiro - 2. ed. - São Paulo: Atlas, 2016.

CAMBI, Eduardo. Neoconstitucionalismo e neoprocessualismo: direitos fundamentais, políticas públicas e protagonismo judiciário. - 2. ed. - São Paulo: Almedina, 2018.

COSTIN, Claudia. Administração pública. - Rio de Janeiro: Elsevier, 2010.

FREITAS, Juarez. O controle dos atos administrativos e os princípios fundamentais. $-5^{\mathrm{a}}$ ed. - São Paulo: Malheiros Editores, 2013.

HÄBERLE, Peter. Hermenêutica constitucional a sociedade aberta dos intérpretes da Constituição: contribuição para a interpretação pluralista e "procedimental" da Constituição. Tradução de Gilmar Ferreira Mendes. - Porto Alegre: Sergio Antonio Fabris Editor, 2002.

MARQUES NETO, Floriano de Azevedo; FREITAS, Rafael Véras de. A Constituição de 1988 e o direito administrativo: histórias de uma relação dialética entre avanços e retrocessos. In: TOFFOLI, José Antônio Dias (organizador). 30 anos da constituição brasileira: democracia, direitos fundamentais e instituições. - Rio de Janeiro: Forense, 2018. p. 621-642. 
NERY JUNIOR, Nelson. Princípios do processo na Constituição Federal: (processo civil, penal e administrativo) - 12. ed. rev., ampl. e atual. com as novas súmulas do STF (simples e vinculantes) e com o novo CPC (Lei 13.105/2015) - São Paulo: Editora Revista dos Tribunais, 2016.

NEVES, Daniel Amorim Assumpção. Código de Processo Civil comentado - 4. ed. rev. e atual. - Salvador: ed. JusPodivm, 2019.

SARLET, Ingo Wolfgang. A eficácia dos direitos fundamentais: uma teoria geral dos direitos fundamentais na perspectiva constitucional - 12. ed. rev. atual. e ampl. Porto Alegre: Livriaria do Advogado Editora, 2015.

THEODORO JÚNIOR, Humberto. Código de Processo Civil anotado - 20. ed. revista e atualizada - Rio de Janeiro: Forense, 2016.

ZUFELATO, Camilo. Contraditório e vedação às decisões-surpresa no processo civil brasileiro. - Belo Horizonte: Editora D'Plácido, 2019. 